\title{
PERSEPSI PELAKU USAHA PERIKANAN TERHADAP KINERJA PENYULUH PERIKANAN
}

\author{
Oleh: \\ Nayu Nurmalia, Ani Leilani, Azam B. Zaidy \\ Dosen Jurusan Penyuluhan Perikanan, Sekolah Tinggi Perikanan
}

\begin{abstract}
ABSTRAK
Penelitian mengenai persepsi pelaku usaha terhadap kinerja penyuluh perikanan dilakukan pada bulan April sampai bulan Mei 2011. Lokasi penelitian di 11 provinsi yang tersebar di 13 kabupaten/kota. Jumlah responden sebanyak 89 orang. Penelitian ini bertujuan untuk mengetahui persepsi pelaku usaha perikanan terhadap kinerja penyuluh perikanan. Hasil penelitian menunjukkan keberadaan penyuluh masih sangat dibutuhkan oleh pelaku usaha, materi yang dibutuhkan terkait dengan peningkatan produksi usahanya, dan cara yang diinginkan pelaku usaha adalah penyuluh dapat memberi contoh usaha perikanan sesuai kebutuhan pelaku usaha.
\end{abstract}

Kata kunci: Persepsi, Pelaku usaha perikanan, Penyuluh Perikanan

PENDAHULUAN

\section{Latar Belakang}

Pembangunan perikanan sesuai yang diamanatkan Undang-Undang Nomor 16 Tahun 2006 merupakan suatu keharusan untuk meningkatkan kesejahteraan rakyat. Dalam meningkatkan peran sektor perikanan diperlukan sumberdaya yang berkualitas, andal, serta berkemampuan manajerial, kewirausahaan dan organisasi bisnis sehingga pelaku pembangunan perikanan mampu membangun usaha dari hulu sampai hilir yang berdaya saing tinggi.

Pelaku usaha perikanan adalah perorangan warga negara Indonesia atau badan hukum yang dibentuk menurut hukum Indonesia yang mengelola sebagian atau seluruh kegiatan usaha perikanan dari hulu sampai hilir. Persepsi pelaku usaha perikanan adalah suatu proses aktivitas dalam memberikan kesan, penilaian, pendapat, merasakan dan menginterpretasikan sesuatu berdasarkan informasi yang ditampilkan dari sumber lain (yang dipersepsi), dalam hal ini kaitan persepsi terhadap kinerja yang dilakukan penyuluh perikanan .

Penyuluh perikanan memiliki peran yang sangat strategis dalam upaya peningkatan perekonomian masyarakat Indonesia khususnya di bidang kelautan dan perikanan, karena dalam pelaksanaan tugas dan tanggung jawabnya merupakan tenaga yang banyak berhubungan langsung dengan pelaku usaha perikanan di lapangan terutama dengan nelayan, pengolah dan pembudidaya perikanan.

Sumarjo (2008) mengemukakan bahwa kompetensi penyuluh adalah karakteristik yang melekat pada diri 
penyuluh yang menentukan keefektifan kinerja penyuluh dalam mengemban misi penyuluhan. Kinerja atau performasi adalah hasil kerja yang dapat dicapai seseorang atau kelompok orang dalam organisasi, sesuai dengan wewenang dan tanggung jawab masing-masing dalam rangka mencapai tujuan organisasi. Penyuluh perikanan sesuai Peraturan Pemerintah Nomor 19 Tahun 2008 adalah jabatan yang mempunyai ruang lingkup tugas, tanggung jawab dan wewenang untuk penyuluhan perikanan yang diduduki oleh pegawai negeri sipil dengan hak dan kewajiban secara penuh yang diberikan oleh pejabat yang berwenang. Kinerja penyuluh perikanan merupakan perwujudan diri atas sejauhmana tugas pokoknya dapat dilaksanakan sesuai dengan patokan yang telah ditetapkan.

\section{Tujuan Penelitian}

Penelitian ini bertujuan untuk mengetahui persepsi pelaku usaha perikanan terhadap kinerja penyuluh perikanan yang dibutuhkan oleh pelaku usaha.

\section{Kegunaan Penelitian}

Hasil penelitian diharapkan dapat dijadikan sebagai bahan pertimbangan dalam mengevaluasi kegiatan penyuluh perikanan sesuai kinerjanya yang dibutuhkan oleh pelaku usaha.

\section{METODE PENELITIAN}

Penelitian ini dilakukan pada bulan April-Mei 2011 di 11 provinsi yaitu Kepulauan Riau, Bengkulu, Sumatera Selatan, Banten, Jawa Barat, Jawa Tengah, DI Yogyakarta, Jawa Timur, Kalimantan Barat, Bali, dan Sulawesi Selatan, yang tersebar di 13 kabupaten/kota yaitu Bintan, Kota Bengkulu, Kota Palembang, Pandeglang, Sumedang, Tasikmalaya,
Boyolali, Gunung Kidul, Kulonprogo, Pacitan, Sambas, Bangli, dan Maros.

Populasi dalam penelitian ini adalah semua pelaku usaha budidaya perikanan di 13 Kabupaten/Kota: Bintan, Kota Bengkulu, Kota Palembang, Pandeglang, Sumedang, Tasikmalaya, Boyolali, Gunung Kidul, Kulonprogo, Pacitan, Sambas, Bangli, dan Maros. Responden diambil secara acak dengan jumlah responden 89 orang.

Penelitian berbentuk survei deskriptif yaitu penelitian untuk membuat pencandraan (deskripsi) mengenai situasi-situasi atau kejadian-kejadian, mengidentifikasi masalahmasalah atau untuk mendapatkan justifikasi keadaan dan praktek-praktek yang sedang berlangsung (Suryabrata , 2003). Pengumpulan data diambil berdasarkan hasil wawancara dengan responden menggunakan kuesioner. Data yang terkumpul ditabulasi, dianalisis serta dilakukan pengkategorian sesuai dengan skor.

\section{HASIL DAN PEMBAHASAN}

\section{Deskripsi Daerah Penelitian}

Daerah penelitian tersebar di 13 kabupaten/kota yang ada di 11 povinsi yang meliputi kabupaten/kota: Bintan, Kota Bengkulu, Kota Palembang, Pandeglang, Sumedang, Tasikmalaya, Boyolali, Gunung Kidul, Kulonprogo, Pacitan, Sambas, Bangli, dan Maros. Lokasi penelitian merupakan wilayah yang mempunyai potensi perikanan dengan pelaku usaha sebagian besar usaha budidaya perikanan air tawar.

\section{Persepsi Pelaku Usaha Terhadap Kinerja Penyuluh Perikanan}

Persepsi pada hakikatnya adalah merupakan proses penilaian seseorang terhadap obyek tertentu. Di dalam proses persepsi individu dituntut untuk memberikan penilaian terhadap suatu obyek yang dapat bersifat positif/negatif, senang atau tidak 
senang dan sebagainya. Istilah persepsi adalah suatu proses aktivitas seseorang dalam memberikan kesan, penilaian, pendapat, merasakan dan menginterpretasikan sesuatu berdasarkan informasi yang ditampilkan dari sumber lain (yang dipersepsi). Persepsi merupakan proses psikologis dan hasil dari penginderaan serta proses terakhir dari kesadaran, sehingga membentuk proses berpikir. Pada kenyataannya sebagian besar sikap, tingkah laku dan penyesuaian ditentukan oleh persepsinya.

Persepsi pelaku usaha terhadap kinerja penyuluh perikanan meliputi persepsi terhadap keberadaan penyuluh perikanan di wilayah usahanya, persepsi sikap pelaku usaha terhadap tingkat kebutuhan bantuan penyuluh perikanan dalam memajukan usaha yang ditekuni pelaku usaha, persepsi pelaku usaha terhadap jenis bantuan yang diharapkan dari penyuluh perikanan, persepsi pelaku usaha terhadap frekuensi kehadiran penyuluh perikanan yang dibutuhkan di lokasi usaha, persepsi pelaku usaha terhadap cara penyuluh memberikan penyuluhan, persepsi pelaku usaha terhadap harapan dengan adanya kelompok usaha perikanan, persepsi cara pelaku usaha dalam menyelesaikan masalah yang dihadapi dalam usahanya.

\section{Persepsi Pelaku Usaha terhadap Keberadaan Penyuluh Perikanan}

Penyuluh penyuluh perikanan berdasarkan kondisi di lapangan masih kurang. Keberadaan penyuluh perikanan dalam kegiatan penyuluhan kepada pelaku usaha masih sangat diperlukan.

Tabel 1. Persentase persepsi pelaku usaha terhadap keberadaan penyuluh perikanan di wilayah usahanya

\begin{tabular}{|l|c|c|}
\hline \multicolumn{1}{|c|}{ Kategori } & Jumlah Pelaku Usaha & Persentase \\
\hline Sangat Kenal & 29 & 33 \\
\hline Kenal & 51 & 57 \\
\hline Sudah Lupa & 0 & 0 \\
\hline Tidak Kenal & 9 & 10 \\
\hline Jumlah & 89 & 100 \\
\hline
\end{tabular}

Keberadaan Tabel 1 menunjukkan bahwa pelaku usaha mengenal keberadaan penyuluh perikanan di wilayah usahanya pada kaegori sangat kenal 33\% (29 orang), pada kategori kenal 57\% (51 orang) dan yang ragu-ragu 0\% (0 orang) serta pada kategori yang tidak kenal penyuluh perikanan 10\% (9 orang).

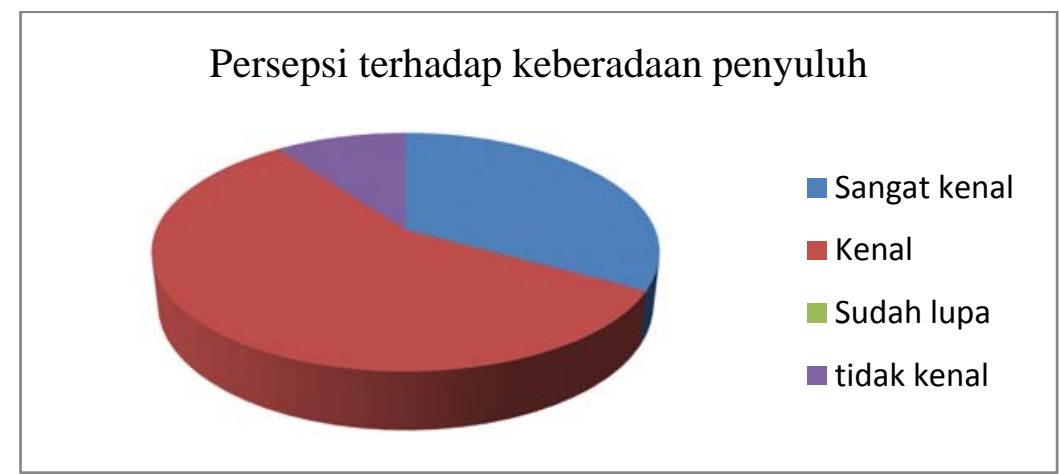

Hasil tersebut dapat disimpulkan terhadap keberadaan penyuluh perikanan bahwa persepsi sebagian besar pelaku usaha dengan kategori sangat kenal dan kenal 
(90\%) menyatakan bahwa penyuluh perikanan sering menemui pelaku usaha dalam melakukan kegiatan penyuluhan yang menjadi tugasnya. Persepsi sebagian besar pelaku usaha perikanan mengenal/kenal penyuluh perikanan, hal tersebut juga dapat dibuktikan bahwa sebanyak 64 orang (72\%) responden dapat menyebutkan nama penyuluh perikanan yang ada di wilayah usahanya.

Persepsi Pelaku Usaha terhadap Tingkat Kebutuhan Bantuan Penyuluh Perikanan

Hasil penelitian menunjukkan bahwa persepsi pelaku usaha terhadap tingkat kebutuhan bantuan penyuluh perikanan dengan kategori sangat perlu 45\%, (40 orang) kategori perlu 53\% (47 orang), dan sisanya 2\% (2 orang) termasuk kategori yang ragu-ragu dan tidak perlu.

Tabel 2. Persentase Persepsi sikap pelaku usaha terhadap tingkat kebutuhan bantuan penyuluh perikanan dalam memajukan usaha yang ditekuni pelaku usaha

\begin{tabular}{|l|c|c|}
\hline \multicolumn{1}{|c|}{ Kategori } & Jumlah Pelaku Usaha & Persentase \\
\hline Sangat Perlu & 40 & 45 \\
\hline Perlu & 47 & 53 \\
\hline Ragu-ragu & 1 & 1 \\
\hline Tidak Perlu & 1 & 1 \\
\hline Jumlah & 89 & 100 \\
\hline
\end{tabular}

Hasil pada Tabel 2 memperlihatkan bahwa pelaku usaha masih sangat membutuhkan kehadiran penyuluh perikanan dalam memajukan usaha yang ditekuninya. Kehadiran penyuluh perikanan dipandang masih sangat diperlukan dalam tugas pendampingan dan konsultasi bagi pelaku usaha dalam mengembangkan kegiatan usaha perikanan yang sedang digelutinya.

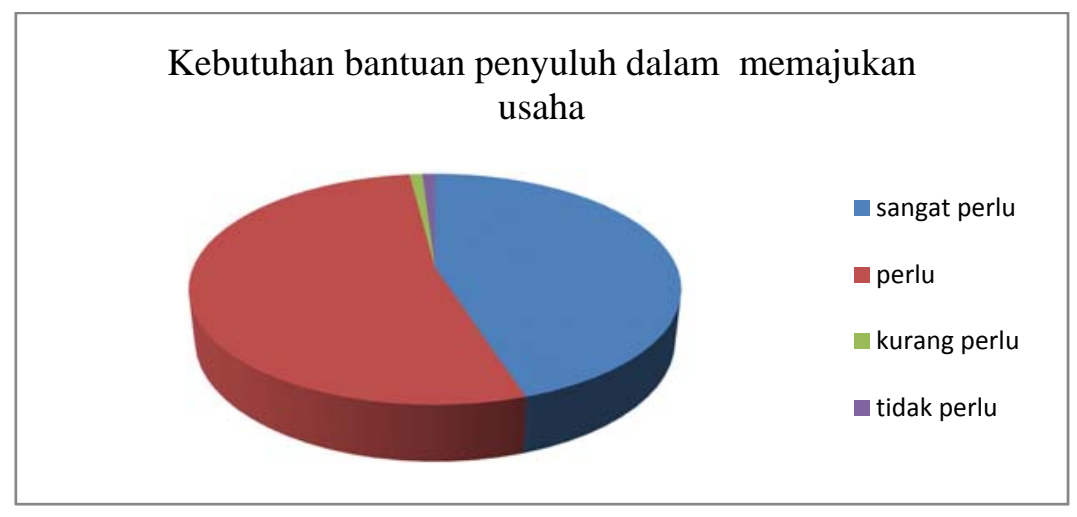

Persepsi Pelaku Usaha terhadap Jenis Bantuan dari Penyuluh Perikanan

Pelaku usaha perikanan pada kenyataannya masih membutuhkan penyuluh perikanan dalam mengelola usaha. Di lapangan, persepsi sebagian besar pelaku usaha terhadap kemampuan penyuluh perikanan yang terkait dengan penguasaan penyuluh mengenai usaha yang dilakukan pelaku dinilai masih sangat dibutuhkan. 
Tabel 3. Persentase persepsi pelaku usaha terhadap jenis bantuan yang diharapkan dari penyuluh perikanan

\begin{tabular}{|l|c|c|}
\hline \multicolumn{1}{|c|}{ Kategori } & Jumlah pelaku usaha & Persentase \\
\hline Meningkatkan produksi & 37 & 42 \\
\hline $\begin{array}{l}\text { Mencarikan bantuan modal } \\
\text { dari pemerintah }\end{array}$ & 20 & 22 \\
\hline $\begin{array}{l}\text { Membantu memasarkan hasil } \\
\text { produksi }\end{array}$ & 19 & 15 \\
\hline $\begin{array}{l}\text { Menghubungkan dengan } \\
\text { sumber permodalan non } \\
\text { pemerintah }\end{array}$ & 13 & 100 \\
\hline Jumlah & 89 & \\
\hline
\end{tabular}

Pada Tabel 3 terlihat bahwa pelaku usaha masih mengharapkan bantuan penyuluh perikanan, dengan jenis bantuan yang diharapkan adalah yang tertinggi pada kategori meningkatkan produksi 42\%, sementara pada kategori mencarikan bantuan modal dari pemerintah dan kategori membantu memasarkan hasil produksi masing-masing $22 \%$ dan $21 \%$.

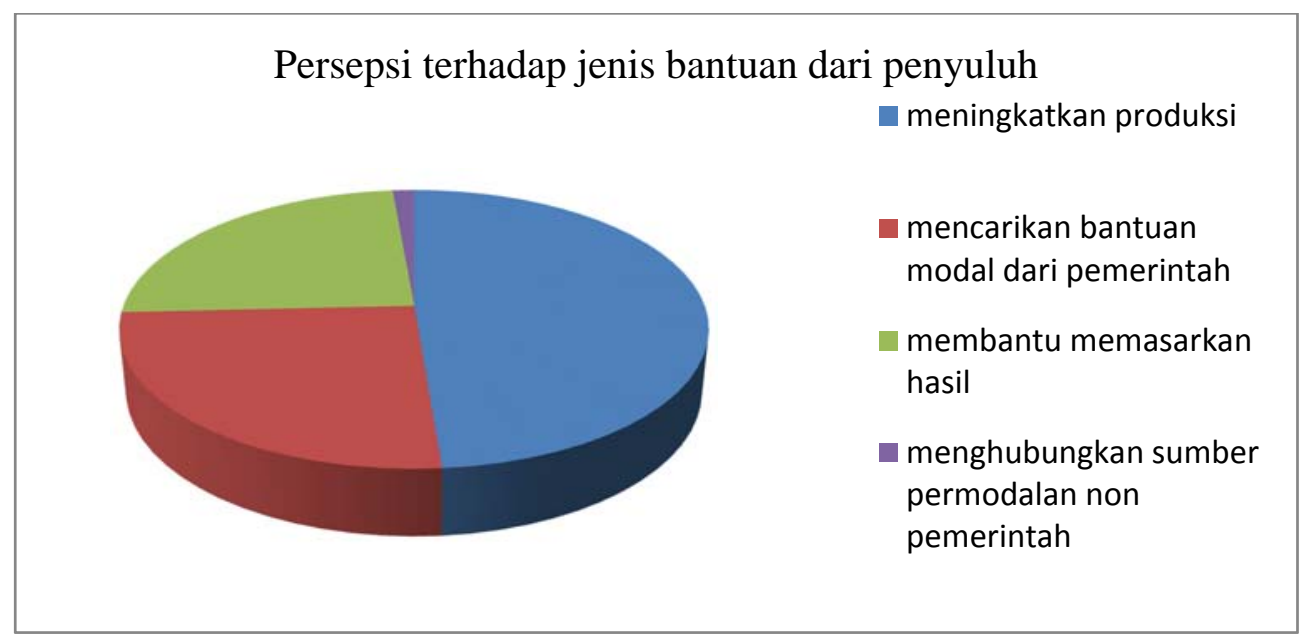

Sesuai dengan kebutuhan bantuan yang dilharapkan pelaku usaha dari penyuluh perikanan yang paling tinggi dalam meningkatkan produksi, maka materi penyuluhan yang diberikan harus sesuai yang dibutuhkan pelaku usaha. Peran penyuluh perikanan tidak sekedar mentransfer teknologi dan informasi, peran penyuluh harus dapat pengidentifikasi permasalahan dan kebutuhan pelaku usaha. Keseluruhan peran tersebut dibutuhkan untuk menghadapi dinamika perubahan dalam kehidupan masyarakat perikanan dan memenuhi prinsip penyuluhan yang mengembangkan kemandirian pelaku usaha, bukan ketergantungan kepada pihak lain. 
Persepsi Pelaku Usaha terhadap Frekuensi Kehadiran Penyuluh Perikanan

Hasil penelitian menunjukkan bahwa pelaku usaha membutuhkan kehadiran penyuluh perikanan pada kategori dua minggu sekali (37\%) dan seminggu sekali (34\%). Hasil ini memperlihatkan bahwa pelaku usaha masih membutuhkan penyuluh perikanan dengan frekuensi kehadiran yang cukup tinggi (71\%), sedangkan sisanya menyatakan bahwa penyuluh perikanan frekuensi kehadirannya cukup sebulan sekali (17\%) dan kategori kehadiran penyuluh pada saat dibutuhkan saja hanya $12 \%$.

Tabel 4. Persentase persepsi pelaku usaha terhadap frekuensi kehadiran penyuluh perikanan yang dibutuhkan di lokasi usaha

\begin{tabular}{|l|c|c|}
\hline \multicolumn{1}{|c|}{ Kategori } & Jumlah pelaku usaha & Persentase (\%) \\
\hline Seminggu sekali & 30 & 34 \\
\hline 2 minggu sekali & 33 & 37 \\
\hline Sebulan sekali & 15 & 17 \\
\hline Kalau dibutuhkan saja & 11 & 12 \\
\hline Jumlah & 89 & 100 \\
\hline
\end{tabular}

Pelaku usaha mengharapkan kehadiran penyuluh perikanan di lokasi usahanya sesering mungkin, untuk itu penyuluh perikanan dituntut dinamis. Salah satu peran penyuluh sebagai konsultan bagi pelaku usaha, maka penyuluh perikanan harus selalu siap jika dibutuhkan.

\section{Persepsi Pelaku Usaha terhadap Cara Penyuluh Memberikan Penyuluhan}

Penyuluhan semestinya dilakukan dengan pendekatan partisipatif melalui mekanisme kerja dan metode yang disesuaikan dengan kebutuhan serta kondisi pelaku utama dan pelaku usaha. Metode penyuluhan merupakan cara atau teknik penyampaian materi (isi pesan) penyuluhan oleh para penyuluh kepada sasaran (pelaku utama dan/atau pelaku usaha) berserta keluarganya baik secara langsung maupun tidak langsung, agar mereka tahu, mau, dan mampu menerapkan inovasi (Mardikanto, 1993).

Tabel 5. Persentase persepsi pelaku usaha terhadap cara penyuluh memberikan penyuluhan

\begin{tabular}{|l|c|c|}
\hline \multicolumn{1}{|c|}{ Kategori } & Jumlah pelaku usaha & Persentase \\
\hline Memberikan ceramah & 13 & 15 \\
\hline Menonton film/video & 1 & 1 \\
\hline Membagikan brosur/folder & 1 & 1 \\
\hline Memiliki contoh usaha & 74 & 83 \\
\hline Jumlah & 89 & 100 \\
\hline
\end{tabular}

Berdasarkan hasil penelitian, persepsi pelaku usaha terhadap cara penyuluh dalam memberikan penyuluhan dengan persentase tertinggi adalah pelaku usaha menginginkan bahwa penyuluh memiliki contoh usaha (83\%). Hal ini menunjukkan bahwa keteladanan (menajdi contoh) seorang penyuluh masih diharapkan oleh pelaku 
usaha terutama dalam hal yang berkaitan dengan usaha yang dilakukannya. Persepsi pelaku usaha terhadap cara penyuluh memberikan penyuluhan dalam bentuk ceramah, menonton film/video dan membagikan brosur/folder dengan jumlah rendah yaitu $17 \%$.

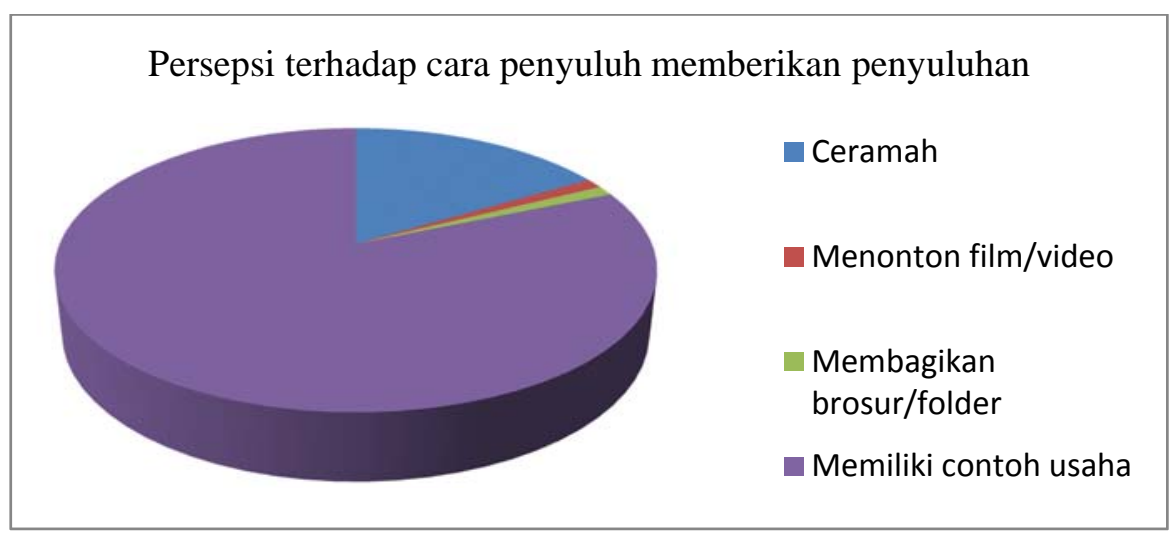

Persepsi Pelaku Usaha Terhadap Harapan dengan adanya Kelompok

Kelompok adalah himpunan atau kesatuan manusia yang hidup bersama sehingga terdapat hubungan yang timbal balik dan saling pengaruh- mempengaruhi serta memiliki kesadaran saling tolong menolong (Van Den Ban, 1999.)

Tumbuh dan kembangnya kelompokkelompok dalam masyarakat pada umumnya didasarkan atas adanya kepentingan bersama, sedangkan kekompakan kelompok tergantung pada faktor pengikat yang dapat menciptakan keakraban individu yang bergabung didalam kelompok. Faktor pengikat yang paling umum biasanya perasaan dan kesamaan yang bisa menciptakan keakraban dalam kehidupan sehari-hari dan dapat memberikan keuntungan timbal balik. Manusia dapat berkembang dan meningkatkan kualitasnya dengan bergabung atau tergabung dalam kelompok, namun hanya kelompok yang efektif yang dapat meningkatkan kualitas manusia (Huraerah dan Purwato, 2006).

Tabel 6. Persentase persepsi pelaku usaha terhadap harapan dengan adanya kelompok usaha perikanan

\begin{tabular}{|l|c|c|}
\hline \multicolumn{1}{|c|}{ Kategori } & Jumlah pelaku usaha & Persentase (\%) \\
\hline Pengadaan benih dan pakan & 22 & 25 \\
\hline Memberi pinjaman modal & 14 & 15 \\
\hline Membantu memasarkan hasil & 22 & 25 \\
\hline $\begin{array}{l}\text { Memberi informasi cara } \\
\text { produksi }\end{array}$ & 31 & 35 \\
\hline Jumlah & 89 & 100 \\
\hline
\end{tabular}

Persepsi pelaku usaha terhadap harapan adanya kelompok usaha perikanan seperti pada data Tabel 6 menunjukkan bahwa kategori memberi informasi cara produksi dengan persentase yang paling tinggi (35\%), walaupun persepsi terhadap pengadaan benih dan pakan serta persepsi membantu memasarkan hasil masing-masing juga dengan persentase yang sama tinggi (25\%), dan memberi pinjaman modal (15\%). 


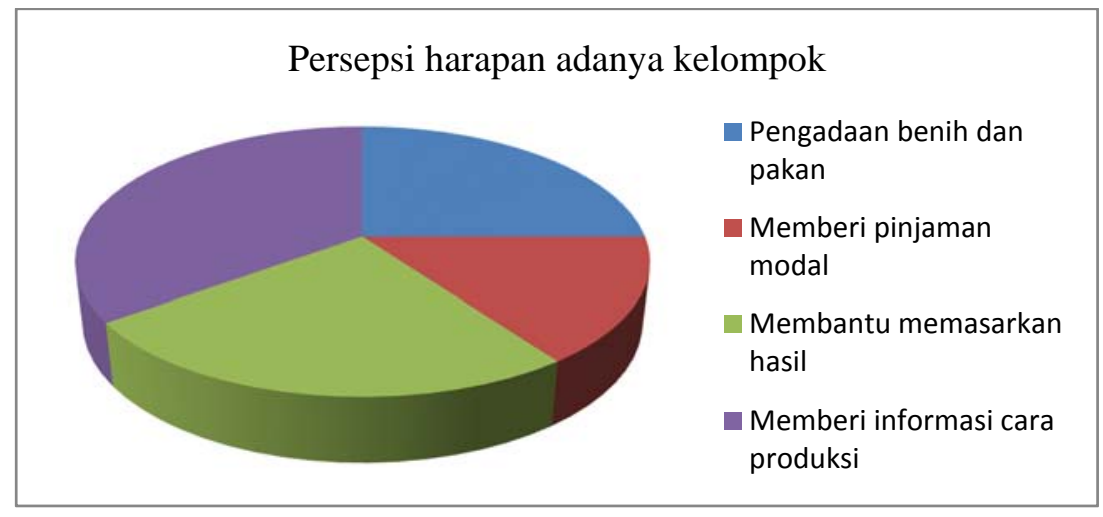

Dengan adanya kelompok tidak terlepas dari tujuan terbentuknya kelompok, yaitu adanya kepentingan yang sama setiap pelaku usaha. Karakteristik kelompok pelaku utama atau pelaku usaha meliputi ciri, unsur pengikat dan fungsi dari kelompok tersebut. Fungsi kelompok sesuai dengan KEP. MEN KP Nomor 14 Tahun 2012 tentang Pedoman Umum Penumbuhan dan Pengembangan Kelembagaan Pelaku Utama Perikanan, terdiri atas sembilan fungsi yaitu wadah proses pembelajaran, wahana kerjasama, unit penyedia sarana dan prasarana produksi perikanan, unit produksi perikanan, unit pengolahan dan pemasaran, unit jasa penunjang, organisasi kegiatan bersama, dan kesatuan swadaya dan swadana. Berdasarkan hasil pada gambar di atas menunjukkan bahwa harapan pelaku usaha dengan adanya kelompok masih menginginkan fungsifungsi kelompok dijalankan dengan baik. Fungsi-fungsi kelompok tersebut seperti yang tersurat dalam KEP.MEN KP No 14 Tahun 2012.

\section{Persepsi Pelaku Cara Pelaku Usaha dalam Menyelesaikan Masalah yang dihadapi dalam Usaha}

Pelaku usaha memiliki kemampuan tertentu dalam usahanya, dan mempunyai kemauan untuk mengembangkannya. Untuk membantu mereka membantu dirinya sendiri, maka kemampuan dan kemauan yang ada harus diketahui dengan baik, karena kegiatan penyuluhan yang efektif dimulai dari kemauan dan kemampuan yang mereka miliki (Tjitropranoto, 2003).

Tabel 7. Persentase persepsi cara pelaku usaha dalam menyelesaikan masalah yang dihadapi dalam usahanya.

\begin{tabular}{|l|c|c|}
\hline \multicolumn{1}{|c|}{ Kategori } & Jumlah pelaku usaha & Persentase \\
\hline Menunggu penyuluh datang & 6 & 7 \\
\hline Menemui penyuluh & 35 & 39 \\
\hline Menelpon penyuluh & 20 & 23 \\
\hline Menghubungi teman usaha & 28 & 31 \\
\hline Jumlah & 89 & 100 \\
\hline
\end{tabular}

Pada dasarnya pelaku usaha dalam menyelesaikan masalah usahanya memiliki caranya masing-masing. Data yang terlihat pada Tabel 7 menunjukkan bahwa pelaku usaha dalam menyelesaikan masalah yang dihadapi dalam usahanya sebagian besar menemui penyuluh (39\%) dan menghubungi teman usahanya (31\%). Selain itu juga pelaku usaha menelpon penyuluh (23\%) jika menghadapi masalah usaha, hanya ada 
sebagian kecil saja (7\%) yang menunggu penyuluh datang.

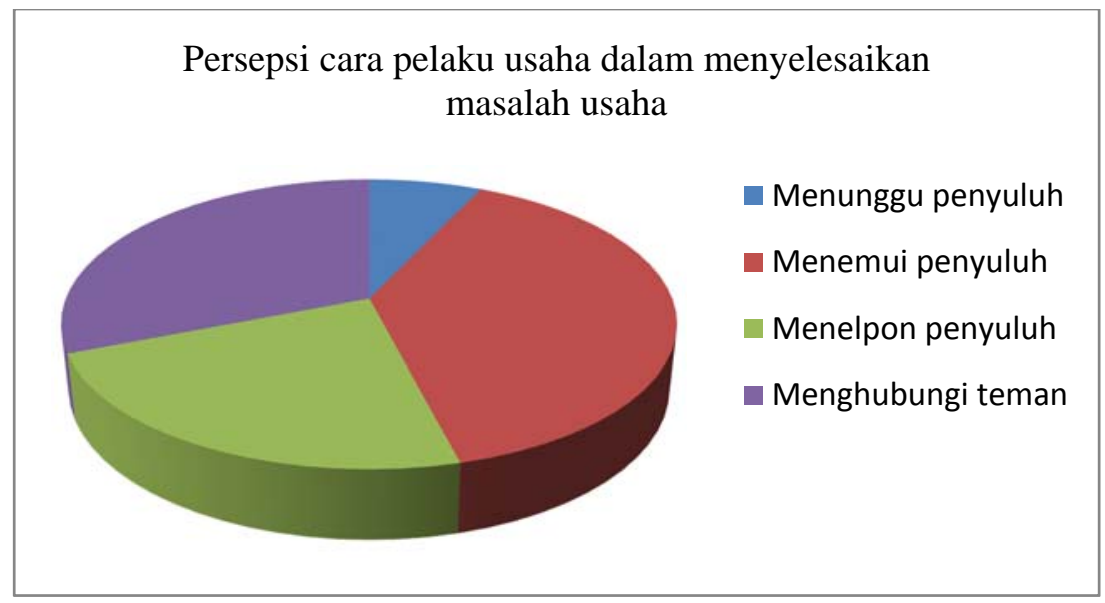

Menurut Tjitropranoto (2003), kegiatan penyuluhan harus menekankan upaya membantu pelaku usaha agar dapat membantu dirinya sendiri (helping people help themselves). Penyuluh harus mampu merespon perubahan perilaku pelaku utama/pelaku usaha.

\section{KESIMPULAN}

Berdasarkan hasil penelitian persepsi pelaku usaha terhadap kinerja penyuluh perikanan dapat diambil beberapa kesimpulan:

1. Keberadaan penyuluh masih sangat diharapkan oleh pelaku usaha, oleh karena itu penyuluh perikanan harus mampu, siap merespon pelaku usaha, dan penyuluh harus menguasaai dan memanfaatkan teknologi informasi, komunikasi dan edukasi, sehingga keberadaannya mempunyai arti bagi pelaku usaha.

2. Materi penyuluhan perikanan yang dibutuhkan pelaku usaha terutama yang terkait dengan peningkatan produksi bagi kelangsungan usahanya

3. Metode penyuluhan perikanan yang diharapkan pelaku usaha dari penyuluh perikanan yaitu dengan memberi contoh usaha.

\section{DAFTAR PUSTAKA}

Anonim. 2006. Undang-undang Nomor 16 Tahun 2006 tentang Sistem Penyuluhan Pertanian, Perikanan dan Kehutanan.

Anonim. 2012. Keputusan Menteri Kelautan dan Perikanan Republik Indonesia Nomor KEP.14/MEN/2012 tentang Pedoman Umum Penumbuhan dan Pengembangan Kelembagaan Pelaku Utama Perikanan.

Huraerah A, Purwanto. 2006. Dinamika Kelompok: Konsep dan Aplikasi. Bandung: PT. Rafika Aditama.

Mardikato T. 1993. Penyuluhan Pembangunan Pertanian. Surakarta: Universitas Sebelas Maret.

Sumarjo. 2008. Penyuluhan Pembangunan Pilar Pendukung Kemajuan dan Kemandirian Masyarakat. Di dalam Yustina I, Sudradjat A, penyunting.. Pemberdayaan

Manusia Pembangunan Yang bermartabat. Medan: Pustaka Bangsa Press.

Suryabrata S. 2003. Metodologi Penelitian. Jakarta: PT Raja Grafindo Persada. 
Tjitropranoto P. 2003. Penyuluhan Pertanian: Masa Kini dan Masa Depan. Di dalam Yustina I, Sudradjat A., penyunting. Membentuk Pola Perilaku Manusia Pembangunan. Bogor: IPB Press.

Van Den Ban AW, Hawkins HS. 1999.

Penyuluhan Pertanian. Jakarta:

Kanisius 